\title{
Fast and reliable procedure developed to generate soft rot Pectobacteriaceae (Pectobacterium spp. and Dickeya spp.) Tn5 mutants resistant to bacteriophage infection
}

\author{
Robert Czajkowski (D)
}

Received: 10 September 2020 / Revised: 15 October 2020 / Accepted: 18 October 2020 /Published online: 23 October 2020

(C) The Author(s) 2020

\begin{abstract}
A simple and fast procedure has been developed to generate soft rot Pectobacteriaceae (SRP: Pectobacterium spp. and Dickeya spp.) Tn5 mutants in genes encoding receptors used by bacteriophages to interact with their hosts, for the follow-up studies. The procedure is inexpensive and does not require any specialized tools and/or dedicated technical support. The neomycin-resistant SRP Tn5 mutants are generated via conjugation with a transposon donor Escherichia coli ST18 strain (requiring 5-aminolevulinic acid (5-ALA) to survive) carrying pFAJ1819-mini-Tn5-neo ${ }^{R}$. The conjugation is done on solid medium supplemented with 5-ALA. After conjugation bacterial cells are collected, suspended in liquid bacterial medium, added to the suspension containing lytic bacteriophages and incubated for the additional $30 \mathrm{~min}$ with shaking (120 rpm). During this stage, the transposon recipients (Pectobacterium spp. and/or Dickeya spp. Tn5 mutants), susceptible to bacteriophage infection are lysed. Likewise, due to the lack of 5-ALA in the growth medium, E. coli ST18 (transposon donor) cells die at this stage. Finally, after incubation, the bacterial mutants with the
\end{abstract}

The procedure to generate bacteriophage-resistant mutants of Soft Rot Pectobacteriaceae is the object of the patent application P.435204, which has been filed with the Polish Patent Office by University of Gdansk, Poland with inventor Robert Czajkowski.

R. Czajkowski $(\square)$

Division of Biologically Active Compounds, Intercollegiate Faculty of Biotechnology, University of Gdansk and Medical University of Gdansk, Antoniego Abrahama 58, 80-307 Gdansk, Poland

e-mail: Robert.Czajkowski@biotech.ug.edu.pl
Tn5 insertions, resistant to phage infection are selected on solid growth medium supplemented with neomycin. The Tn5 insertion sites are sequenced to acquire knowledge about the Tn5-distrupted genes and their putative function in phage-host interactions. The proposed assay allows generation of a number of immediately-available Tn5 mutants expressing phage-resistant phenotypes in a short time (ca. $48 \mathrm{~h}$ ) that can be later characterized for various other phenotypic features. In this study, as a proof-of-concept, this method has been used to generate Dickeya solani IPO2222 Tn5 mutants resistant to infection caused by the lytic bacteriophage $\phi \mathrm{D} 5$.

Keywords Bacterial viruses $\cdot$ Survival $\cdot$ Phage $\cdot$

Resistance $\cdot$ Transposon mutagenesis $\cdot$ Phage receptors

Bacteriophages (phages) are viruses able to infect and kill bacteria (Abedon 2009). Due to their obligatory parasitic nature, phages are completely dependent on their bacterial hosts to survive and to propagate in the environment (Labrie et al. 2010). Survival and ecological success of bacteriophages is therefore solely linked to their ability to infect the host cell and, once infection has happened, to complete their life cycle within the host. All successful viral infections begin with host recognition and adsorption: an irreversible binding (attachment) of phage tail proteins to the specific components on the surface of bacterial cells named receptors (Bertozzi Silva et al. 2016).

The presence of a specific receptor on the host as well as its three-dimensional structure determine whether a 


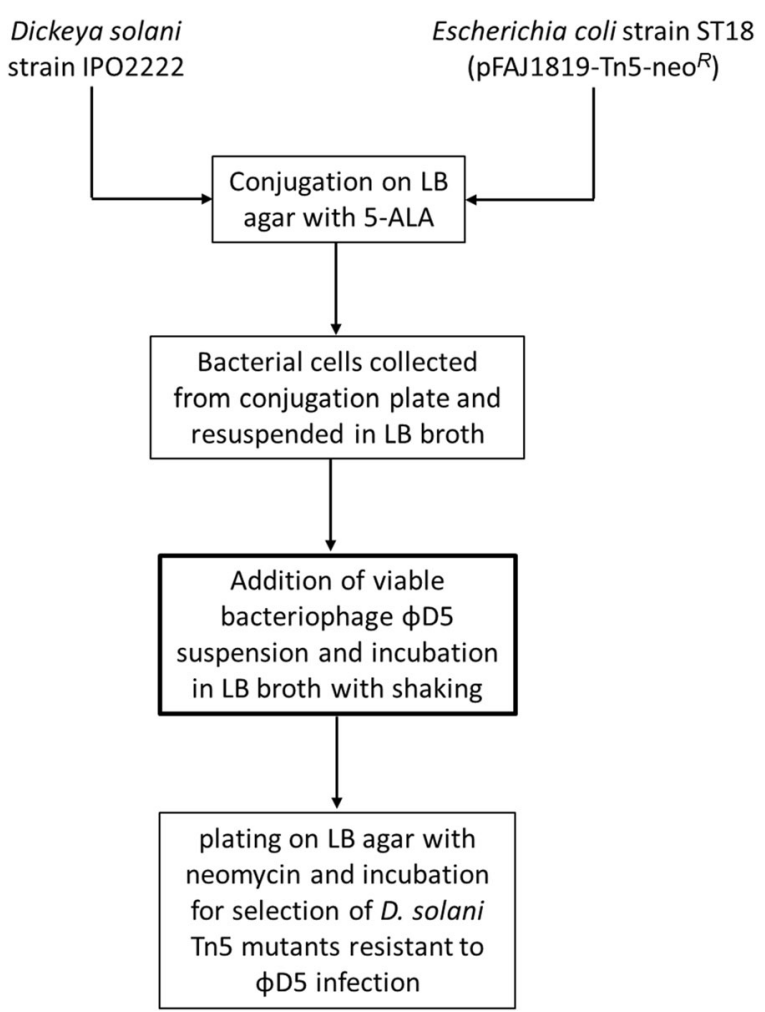

Fig. 1 The scheme of the procedure used to generate phageresistant mutants of Dickeya solani strain IPO2222

particular bacterium is susceptible to phage infection or remains resistant (Lindberg 1973). Although a number of studies has targeted analyses of receptors involved in interaction of model bacterial viruses (e.g. phages $\lambda$ and T4) with the model bacteria (viz. Escherichia coli), still relatively little is known about receptors used by environmental bacteriophages that infect hosts other than E. coli (Rakhuba et al. 2010). Specifically, the knowledge about receptors used by environmental bacteriophages to infect plant pathogenic bacteria is scarce (Bertozzi Silva et al. 2016). A fundamental understanding of the molecular mechanisms governing viral adsorption to the host cell is crucial to assess the role of bacteriophages in environment in adaptation and evolution of their hosts (Samson et al. 2013). Likewise, the knowledge about receptors utilized by bacteriophages is of use when designing viral-based control strategies for bacterial pathogens both in food production and in agriculture (Roach and Debarbieux 2017).

The aim of this study was to develop a simple and fast procedure to generate bacteriophage-resistant soft rot Pectobacteriaceae (SRP) Tn5 mutants. These bacteria are important necrotrophic pathogens infecting a number of commercially-relevant crops worldwide (Charkowski 2018; Pérombelon 2002). The presence of SRP bacteria in crops is linked to increasing losses in agriculture under different climatic conditions (Charkowski et al. 2020) and consequently SRP have been for a long time recognized among the top-ten most important plant pathogenic bacteria (Mansfield et al. 2012). For many years SRP have been a useful model for studying molecular aspects of the plant-bacterium interactions for both monocotyledonous and dicotyledonous plants (Hugouvieux-Cotte-Pattat et al. 1996; Sepulchre et al. 2007), they were however not extensively used as a model to study bacteriophage-bacterial host interactions (Czajkowski 2016, 2019). Analyses of receptors present on the surface of SRP bacteria that are used by bacteriophages for interaction/infection may broaden our understanding of Pectobacterium spp. and Dickeya spp. adaptation in environment as well as their evolution in the presence of bacterial viruses.

To develop and validate a proposed procedure, for the proof-of-concept experiments, the SRP pathogen emerging in Europe, D. solani type strain IPO2222 (van der Wolf et al. 2014), together with its corresponding lytic bacteriophage $\phi \mathrm{D} 5$, characterized in detail in the previous studies (Czajkowski et al. 2013, 2014) were chosen. Unless specifically noted, well-established molecular biology and microbiological methods were used for all described experiments (Sambrook et al. 1989).

For this study, the bacteriophage $\phi \mathrm{D} 5$ was propagated on their wild type bacterial host (D. solani IPO2222) and titer as described earlier (Czajkowski et al. 2013). The adjusted stock concentration of $\phi D 5$ phage particles was $10^{9}$ plaque forming units (pfu) $\mathrm{mL}^{-1}$ in Luria-Bertani broth (LB broth-Miller, Sigma-Aldrich). The experimental methodology to generate bacterial mutants was based on a random transposon mutagenesis of $D$. solani IPO2222 genomes with a mini-Tn5 transposons. To mutate bacterial genomes, conjugation of D. solani IPO2222 (transposon recipient) with Escherichia coli S18 (transposon donor, requiring 5-aminolevulinic acid (5-ALA) to survive) (Thoma and Schobert 2009) carrying pFAJ1819 (obtained from The Belgian Coordinated Collections of Microorganisms - BCCM, Brussels, Belgium) (Xi et al. 1999) suicide vector with mini-Tn5-neo ${ }^{R}$ was performed as previously described (Czajkowski et al. 2017). Briefly, E. coli strain ST18 carrying pFAJ1819-Tn5-neo ${ }^{R}$ was 

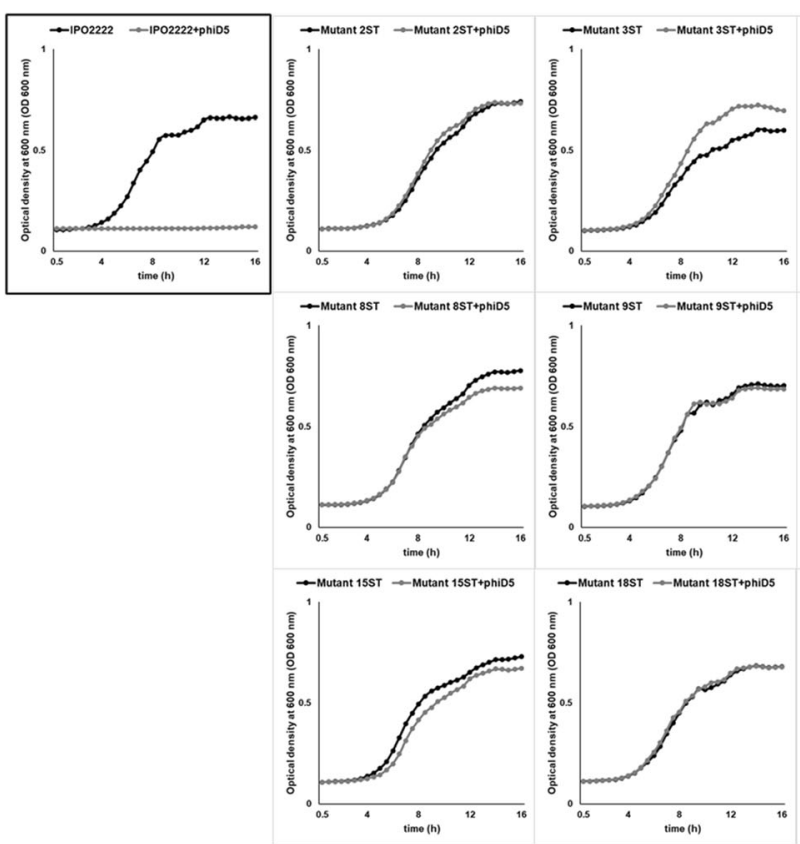

Fig. 2 Host challenge assay of the parental (D. solani IPO2222) strain (marked) and the selected bacteriophage-resistant IPO2222 Tn5 mutants in the absence and presence (+ phiD5) of lytic bacteriophage $\phi D 5$. Per mutant to be analyzed, as described earlier (Czajkowski et al. 2019), in duplicates, the wells of the 96-wells plate were inoculated with $50 \mu \mathrm{l}$ of freshly prepared bacterial cultures (IPO2222 wild type or IPO2222 Tn5 mutants) in LB broth (final $\mathrm{cfu} \mathrm{ml}^{-1}$ of $5 \times 10^{4}$ ). Subsequently, $200 \mu \mathrm{l}$ of

grown in Luria-Bertani broth (LB broth-Miller, Sigma-Aldrich) supplemented with $50 \mu \mathrm{g} \mathrm{mL}^{-1}$ of 5aminolevulinic acid (5-ALA, Sigma-Aldrich) for $16 \mathrm{~h}$ at $37{ }^{\circ} \mathrm{C}$ with shaking $(120 \mathrm{rpm})$ and D. solani strain IPO2222 was grown under the same growth conditions and for the same time but at $28{ }^{\circ} \mathrm{C}$. For the conjugation assay, the equal volumes of the donor $(2 \mathrm{ml})$ and recipient $(2 \mathrm{ml})$ strains, collected after incubation, were individually centrifuged for $3 \mathrm{~min}$. at $8000 \times \mathrm{g}$, washed twice with sterile Ringer's buffer (Merck) and after a second wash, resuspended each in the $500 \mu \mathrm{l}$ of sterile Ringer's buffer. The donor $(0.5 \mathrm{ml})$ and recipient strain $(0.5 \mathrm{ml})$ cultures were mixed together with the equal proportions (1:1), vortexed vigorously for $1 \mathrm{~min}$. and centrifuged for $3 \mathrm{~min}$. at $8000 \times \mathrm{g}$ to sediment the cells. The joint bacterial pellet was resuspended in $15 \mu \mathrm{l}$ of sterile Ringer's buffer and the resulting bacterial suspension (ca. $25 \mu \mathrm{l}$ ) was dropped onto the Luria-Bertani agar (LB agar-Miller, Sigma-Aldrich) plate supplemented with $50 \mu \mathrm{g}$ $\mathrm{mL}^{-1}$ of 5-ALA. Such an inoculated plate was
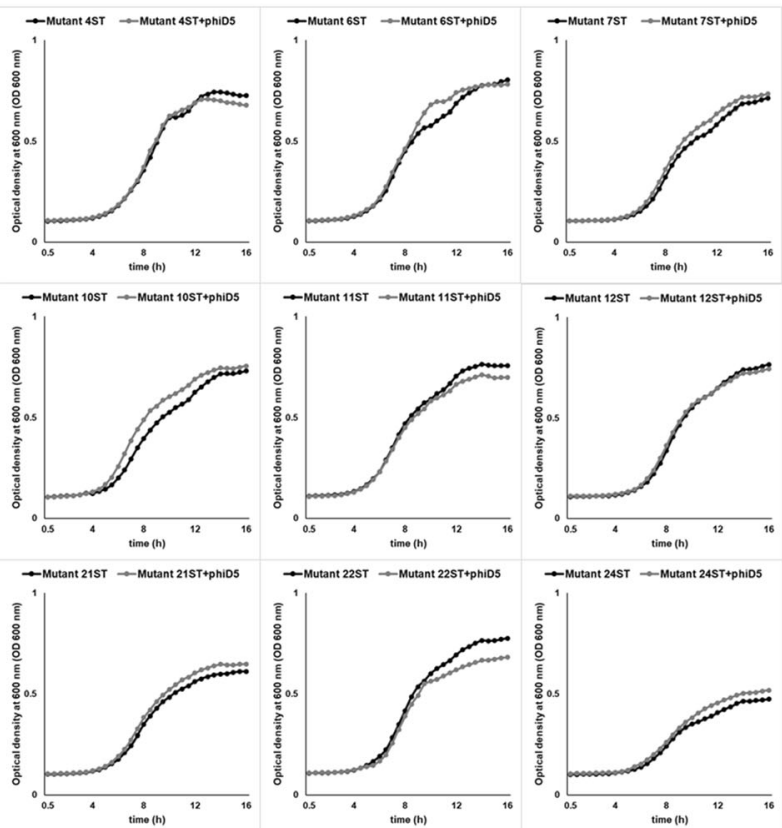

bacteriophage $\phi \mathrm{D} 5$ suspension in LB broth was added per well (final pfu ml $\mathrm{m}^{-1}$ of $2 \times 10^{7}$ ). Inoculated plates were incubated at $28{ }^{\circ} \mathrm{C}$ with shaking (150 rpm). For control instead of bacteriophage suspensions, the sterile LB broth was added. Growth rate was measured as a change in the optic density (OD) of the bacterial cultures at $600 \mathrm{~nm}$ wavelength for the total period of $16 \mathrm{~h}$ every $0.5 \mathrm{~h}$ using Epoch2 Microplate Spectrophotometer (BioTek Instruments)

incubated for $6 \mathrm{~h}$ at $37^{\circ} \mathrm{C}$ for conjugation between donor and recipient to occur. After conjugation, bacterial cells (ca. $10^{8}-10^{9}$ colony forming units (cfu) $\mathrm{mL}^{-1}$ ) were collected from the agar plate using a sterile inoculation loop and resuspended in $500 \mu 1$ of LB broth following addition of a $500 \mu 1$ volume of $\phi \mathrm{D} 5$ suspension in $\mathrm{LB}$ broth containing $10^{9}$ plaque forming units (pfu) $\mathrm{mL}^{-1}$. Such a bacterial suspension $(1 \mathrm{ml})$ was incubated for $30 \mathrm{~min}$. at $28{ }^{\circ} \mathrm{C}$ with shaking $(120 \mathrm{rpm})$ to allow phages to infect and to lyse susceptible $D$. solani Tn5 mutant cells. After this time, $100 \mu 1$ volumes were separately plated on LB agar plates without 5-ALA and supplemented with $50 \mu \mathrm{g} \mathrm{mL^{-1 }}$ of neomycin (Sigma-Aldrich) following incubation for 24-48 h at $28{ }^{\circ} \mathrm{C}$ to select $D$. solani mutants containingTn5 insertions, resistant to $\phi \mathrm{D} 5$ infection. The scheme of the procedure is shown on Fig. 1.

The obtained phage resistant Tn5 mutants selected in this procedure were screened using a plaque formation assay and host challenge assay (Clokie and Kropinski 2009) to confirm the phage resistant phenotype of the each 
Table 1 Plaque formation of lawns of D. solani Tn5 mutants infected with bacteriophage $\phi D 5$. Plaque formation was tested as described earlier (Czajkowski et al. 2013)

\begin{tabular}{lll}
\hline No. & Strain & $\begin{array}{l}\text { Plaque formation } \\
\text { with phage } \phi D 5 \\
\text { on host lawn }\end{array}$ \\
\hline 1 & & $+{ }^{\text {A }}$ \\
2 & D. solani IPO2222 & $-{ }^{\text {B }}$ \\
3 & Mutant 2ST & - \\
4 & Mutant 3ST & - \\
5 & Mutant 4ST & - \\
6 & Mutant 6ST & - \\
7 & Mutant 7ST & - \\
8 & Mutant 8ST & - \\
9 & Mutant 9ST & - \\
10 & Mutant 10ST & - \\
11 & Mutant 11ST & - \\
12 & Mutant 12ST & - \\
13 & Mutant 15ST & - \\
14 & Mutant 18ST & - \\
15 & Mutant 21ST & - \\
16 & Mutant 22ST & Mutant 24ST
\end{tabular}

$\overline{\text { A - indicates formation of bacteriophage plaque (region of host }}$ destruction) on the susceptible host

$\mathrm{B}$ - indicates no plaque formation on phage-resistant host

individual Tn5 mutant analyzed. Additionally, the Tn5 mutants were selected for sequencing the transposon insertion sites as previously described (Lisicka et al. 2018).

In the preliminary assay using the proposed procedure, the 15 D. solani $\mathrm{Tn} 5$ mutants, resistant to bacteriophage $\phi D 5$ were generated and analyzed in time shorter than $48 \mathrm{~h}$. All the $D$. solani mutants were confirmed to be resistant to infections caused by $\phi \mathrm{D} 5$ bacteriophage. Example results are shown in Fig. 2; Table 1 . The Tn5 insertions were found in genes coding for proteins associated with bacterial cell membrane/cell wall, for example: in gene coding for a PTS mannose transporter subunit IID (mutant 9ST), methionine ABC transporter permease (mutant 11ST), sulfate $\mathrm{ABC}$ transporter ATP-binding protein (mutant 12ST), spermidine/ putrescine $\mathrm{ABC}$ transporter ATP-binding protein (24ST) as well as in the couple of cases the transposons were inserted into the genes coding for hypothetical proteins with unknown functions (e.g. in mutant 15ST).
In conclusion, the proposed procedure allows an immediate (time less than $48 \mathrm{~h}$ ) generation of SRP Tn5 mutants resistant to bacteriophage infections for the follow-up studies. These studies may include various phenotypic analyses of phage resistant bacterial strains, investigations of phage-bacteria ecological interactions as well as comparative studies targeting adaptation and fitness of bacterial strains resistant/ susceptible to phage infections in environment. The major advantage of the proposed procedure is that the assay can be completed in a short time and that it does not require the screening of a large collection of Tn5 mutants to find bacteriophage resistant ones. Likewise, the proposed procedure does not require any expensive laboratory tools and consumables and therefore it may be performed in virtually every microbiological laboratory possessing standard microbiological equipment.

It is postulated that due to the universal nature of selection of bacteriophage-resistant Tn5 mutants, this procedure can be easily adapted to generate mutants of other bacterial species and resistant to other lytic bacteriophages of interest.

Acknowledgements The work was financially supported by the National Science Center, Poland (Narodowe Centrum Nauki, Polska) via a research grant NCN OPUS 13 (2017/25/B/NZ9/00036) to Robert Czajkowski. The author would like to express his gratitude to Dr. Sylwia Jafra (University of Gdansk, Poland) for her valuable comments on the manuscript and her editorial work.

\section{Compliance with ethical standards}

The results presented in this manuscript did not involve any protected and/or endangered species, field studies, human participants, specimens or tissue samples, or vertebrate animals, embryos or tissues.

Open Access This article is licensed under a Creative Commons Attribution 4.0 International License, which permits use, sharing, adaptation, distribution and reproduction in any medium or format, as long as you give appropriate credit to the original author(s) and the source, provide a link to the Creative Commons licence, and indicate if changes were made. The images or other third party material in this article are included in the article's Creative Commons licence, unless indicated otherwise in a credit line to the material. If material is not included in the article's Creative Commons licence and your intended use is not permitted by statutory regulation or exceeds the permitted use, you will need to obtain permission directly from the copyright holder. To view a copy of this licence, visit http://creativecommons.org/licenses/by/4.0/. 


\section{References}

Abedon, S. T. (2009). Phage evolution and ecology. Advances in Applied Microbiology, 67, 1-45.

Bertozzi Silva, J., Storms, Z., \& Sauvageau, D. (2016). Host receptors for bacteriophage adsorption. FEMS Microbiology Letters, 363(4), fnw002.

Charkowski, A. (2018). The changing face of bacterial soft-rot diseases. Annual Review of Phytopathology, 56, 269-288.

Charkowski, A., Sharma, K., Parker, M. L., Secor, G. A., \& Elphinstone, J. (2020). Bacterial diseases of potato. In H. Campos \& O. Ortiz (Eds.), The Potato Crop: Its Agricultural, Nutritional and Social Contribution to Humankind (pp. 351-388). Cham: Springer International Publishing.

Clokie, M. R. J., \& Kropinski, A. M. (2009). Bacteriophages: methods and protocols, volume 1: Isolation, characterization, and interactions. New Delhi: Humana Press.

Czajkowski, R. (2016). Bacteriophages of soft rot enterobacteriaceae - a mini-review. FEMS Microbiology Letters, 363, fnv230.

Czajkowski, R. (2019). May the phage be with you? Prophage-like elements in the genomes of Soft Rot Pectobacteriaceae: Pectobacterium spp. and Dickeya spp. Frontiers in Microbiology, 10:138.

Czajkowski, R., Kaczyńska, N., Jafra, S., Narajczyk, M., \& Lojkowska, E. (2017). Temperature-responsive genetic loci in pectinolytic plant pathogenic Dickeya solani. Plant Pathology, 66, 584-594.

Czajkowski, R., Marcisz, M., \& Bartnik, P. (2019). Fast and reliable screening assay developed to preselect candidate Soft Rot Pectobacteriaceae Tn5 mutants showing resistance to bacteriophage infection. European Journal of Plant Pathology, 155, 671-676.

Czajkowski, R., Ozymko, Z., \& Lojkowska, E. (2013). Isolation and characterization of novel soilborne lytic bacteriophages infecting Dickeya spp. biovar 3 ('D. solani'). Plant Pathology, 63, 758-772.

Czajkowski, R., Ozymko, Z., Zwirowski, S., \& Lojkowska, E. (2014). Complete genome sequence of a broad-host-range lytic Dickeya spp. bacteriophage $\phi \mathrm{D} 5$. Archives of Virology, 159, 3153-3155.

Hugouvieux-Cotte-Pattat, N., Condemine, G., Nasser, W., \& Reverchon, S. (1996). Regulation of pectinolysis in Erwinia chrysanthemi. Annual Review of Microbiology, 50, 213-257.

Labrie, S. J., Samson, J. E., \& Moineau, S. (2010). Bacteriophage resistance mechanisms. Nature Reviews Microbiology, 8, 317-327.
Lindberg, A. A. (1973). Bacteriophage receptors. Annual Reviews in Microbiology, 27, 205-241.

Lisicka, W., Fikowicz-Krosko, J., Jafra, S., Narajczyk, M., Czaplewska, P., \& Czajkowski, R. (2018). Oxygen availability influences expression of Dickeya solani genes associated with virulence in potato (Solanum tuberosum L.) and chicory (Cichorium intybus L.). Frontiers in Plant Science, 9, 374.

Mansfield, J., Genin, S., Magori, S., Citovsky, V., Sriariyanum, M., Ronald, M., et al. (2012). Top 10 plant pathogenic bacteria in molecular plant pathology. Molecular Plant Pathology, 13, 614-629.

Pérombelon, M. C. M. (2002). Potato diseases caused by soft rot erwinias: an overview of pathogenesis. Plant Pathology, 51, $1-12$.

Rakhuba, D. V., Kolomiets, E. I., Szwajcer, D. E., \& Novik, G. I. (2010). Bacteriophage receptors, mechanisms of phage adsorption and penetration into host cell. Polish Journal of Microbiology, 59, 145-155.

Roach, D. R., \& Debarbieux, L. (2017). Phage therapy: awakening a sleeping giant. Emerging Topics in Life Sciences, 1, 93103.

Sambrook, J., Fritsch, E. F., \& Maniatis, T. (1989). Molecular Cloning: a laboratory manual. (Cold ed.) Cold Spring Harbor: Spring Harbor Laboratory Press. ISBN: 1936113422.

Samson, J. E., Magadan, A. H., Sabri, M., \& Moineau, S. (2013). Revenge of the phages: defeating bacterial defences. Nature Reviews Microbiology, 11, 675-687.

Sepulchre, J. A., Reverchon, S., \& Nasser, W. (2007). Modeling the onset of virulence in a pectinolytic bacterium. Journal of Theoretical Biology, 244, 239-257.

Thoma, S., \& Schobert, M. (2009). An improved Escherichia coli donor strain for diparental mating. FEMS Microbiology Letters, 294, 127-132.

van der Wolf, J. M., Nijhuis, E. H., Kowalewska, M. J., Saddler, G. S., Parkinson, N., Elphinstone, J. G., et al. (2014). Dickeya solani sp. nov., a pectinolytic plant pathogenic bacterium isolated from potato (Solanum tuberosum). International Journal of Systematic and Evolutionary Microbiology, 64, 768-774.

Xi, C., Lambrecht, M., Vanderleyden, J., \& Michiels, J. (1999). Bi-functional $g f p$-and $g u s A$-containing mini-Tn5 transposon derivatives for combined gene expression and bacterial localization studies. Journal of Microbiological Methods, 35, 85-92. 